\title{
New species of plume moths (Lepidoptera: Pterophoridae) from highlands of the Altai-Sayan mountainous country
}

\section{Новыйвид пальцекрылок (Lepidoptera: Pterophoridae) из высокогорий ААтае-Саянской горной страны}

\author{
P.Ya. Ustjuzhanin ${ }^{1}$, V.N. Kovtunovich ${ }^{2}$ \\ П.Я. Устюжканин ${ }^{1}$, В.Н. Ковтунович ${ }^{2}$
}

\footnotetext{
${ }^{1}$ Altai State University, Lenina 61, Barnaul, 656049 Russia. E-mail: petrust@mail.ru

${ }^{2}$ Moscow Society of Nature Explorers, Bol'shaya Nikitskaya 6, Moscow, RU-103009 Russia. E-mail: vasko-69@mail.ru

${ }^{1}$ Алтайский государственный университет, пр. Ленина 61, Барнаул 656049 Россия.

2 Московское общество испытателей природы, ул. Большая Никитская, 6, Москва, 103009 Россия.
}

KEY WORDS: Pterophoridae, Altai-Sayan mountainous country, new species.

КЛЮЧЕВЫЕ СЛОВА: Пальцекрылки, Алтае-Саянская горная страна, новый вид.

ABSTRACT. The arcticle describes a new species of Pterophoridae - Platyptilia romanorum sp.n., from highlands of the Altai-Sayan mountainous country.

РЕЗЮМЕ. Описывается новый вид пальцекрылки - Platyptilia romanorum sp.n. из высокогорий Алтае-Саянской горной страны.

\section{Introduction}

During the last two decades the material on the rare little-studied species from highlands of the Altai-Sayan mountainous country has been collected, which allowed us to describe a new species. The genus Platyptilia Hübner, [1825] is widely spread in the Palaearctic as well as in the entire world. 5 species are known from the mountains of South Siberia: Platyptilia calodatcyla ([Denis et Schiffermüller], 1775); Platyptilia gonodactyla ([Denis et Schiffermüller], 1775); Platyptilia farfarella Zeller, 1867; Platyptilia nemoralis Zeller, 1841; Platyptilia tesseradactyla (Linnaeus, 1761) [Ustjuzhanin, 1996, Ustjuzhanin, Kovtunovich, 2007]. New species is endemic for the Altai-Sayan mountainous country. The holotype and part of paratypes are deposited in the Zoological Institute (Sankt-Petersburg, ZISP), paratypes are also deposited in the collections of Institute of Systematics and Ecology of Animals (Novosibirsk, ISEA), Zoological museum of Moscow State University (ZMMU) and the private collection of P. Ustjuzhanin and V. Kovtunovich (Novosibirsk and Moscow, CUK).

Abbreviations:

CUK - Collection by P. Ustjuzhanin and V. Kovtunovich (Novosibirsk and Moscow, Russia).

ISEA - Institute of Systematics and Ecology of Animals, Novosibirsk, Russia.

ZISP - Zoological Institute, Sankt-Petersburg, Russia. ZMMU - Zoological Museum of the Moscow State

University, Moscow, Russia.

\section{Platyptilia romanorum \\ Ustjuzhanin et Kovtunovich, sp.n. \\ Figs 1-4.}

MATERIAL. Holotype: $\circ$ (ZISP gen. pr. 1895), RUSSIA: South Altai: Ukok plateau, southern slope of mt. Maytobe, $2650 \mathrm{~m}$, 07.vii.1997, R. Yakovlev. Paratypes: 1 O', (CUK) RUSSIA: South Altai: Ukok plateau, Kara-Chat, 2200 m, 14.vii.1995, A. Bidzilya; 1 $0^{7}$, (ISEA) RUSSIA: South Altai: Ukok plateau, 19.-25.vii.2001, A. Bidzilya; 1 , , (CUK) RUSSIA: South Altai: Ukok plateau, Korsulu Pass, 2800 m, 10.vii.2008, R. Yakovlev, E. Gus'kova; RUSSIA: 10 ex., (ZISP gen. pr. 1896, ZMMU, ISEA, CUK) Central Altai: $15 \mathrm{~km}$ NE vill. Aktash, Yarly-Ayry riv., 2300-2700 m, 9.-13.vii.1999, R. Yakovlev; $20^{\top} \sigma^{7}, 1$, (ZISP, ISEA, CUK) RUSSIA: Central Altai: 15 km NE vill. Aktash, Yarly-Ayry riv., 2200 m, 11.vii.1999, V. Doroshkin; $1 \bigcirc^{7}, 1 \bigcirc$, (CUK) RUSSIA: Central Altai, upper reaches of YarlyAyry riv., 3000 m, 8.vii.2001, A. Nakonechnyi; $1 \sigma^{7}, 1$, (ISEA) RUSSIA: Central Altai: upper reaches of Yarly-Ayry riv., 2400-2800 m, 3.vii.2008, R. Dudko, V. Zinchenko; 2 오, (CUK) RUSSIA: SE Altai: Kosh-Agach distr., riv. Zhumaly, 16.vii.1988, V. Ivonin; 2 $\sigma^{\top} \sigma^{7}, 1$, (ISEA, CUK) RUSSIA: SE Altai: Kosh-Agach distr., left bank of Akturu riv., 2400-2800 m, 14.vii.2006, R. Dudko; $2 \sigma^{7} \sigma^{7}$, (ISEA, CUK) NE KAZAKHSTAN: Tarbagatai Mts., Burhat Pass, 2200-2300 m, 23.vi.1997, R. Dudko, V. Zinchenko.

DESCRIPTION: External characteristics (Figs 1-2). Wingspan $18-23 \mathrm{~mm}$. Head, thorax and tegulae pale yellow. Labial palpi straight, tapered to apices, 1.5 times bigger than eye diameter. Antennae thin, pale brown. Fore wings pale yellow, costal edge pale brown, costal triangle brown. Distinct white band in distal part of both lobes. Outer edge of fringe brown. Fringe inside cleft white. Hind wings unicolorous, pale brown, wide oblique white band in distal part of first lobe. Bunch of brown scales in middle part of third lobe on outer edge. Legs yellowish brown. White sputtering of scales on wings underside, expressed on two first lobes up to cleft base. Third lobe of hind wing from underside completely clarified with white scales.

Male genitalia (Fig. 3). Valves quite narrow, outer edge concave. Uncus narrow, noticeably thicker in apical part. Anellus arms short, slightly bent inside. Saccus with wide notched outer edge. Oval cut on inner edge of saccus. Phallus sharply bent, almost at right angle; basal process of phallus quite long, equal to coecum in length.

Female genitalia (Fig. 4). Papillae anales short, wideoval. Posterior apophyses thin, long. Anterior apophyses long, almost equal to posterior apophyses in length, split in 


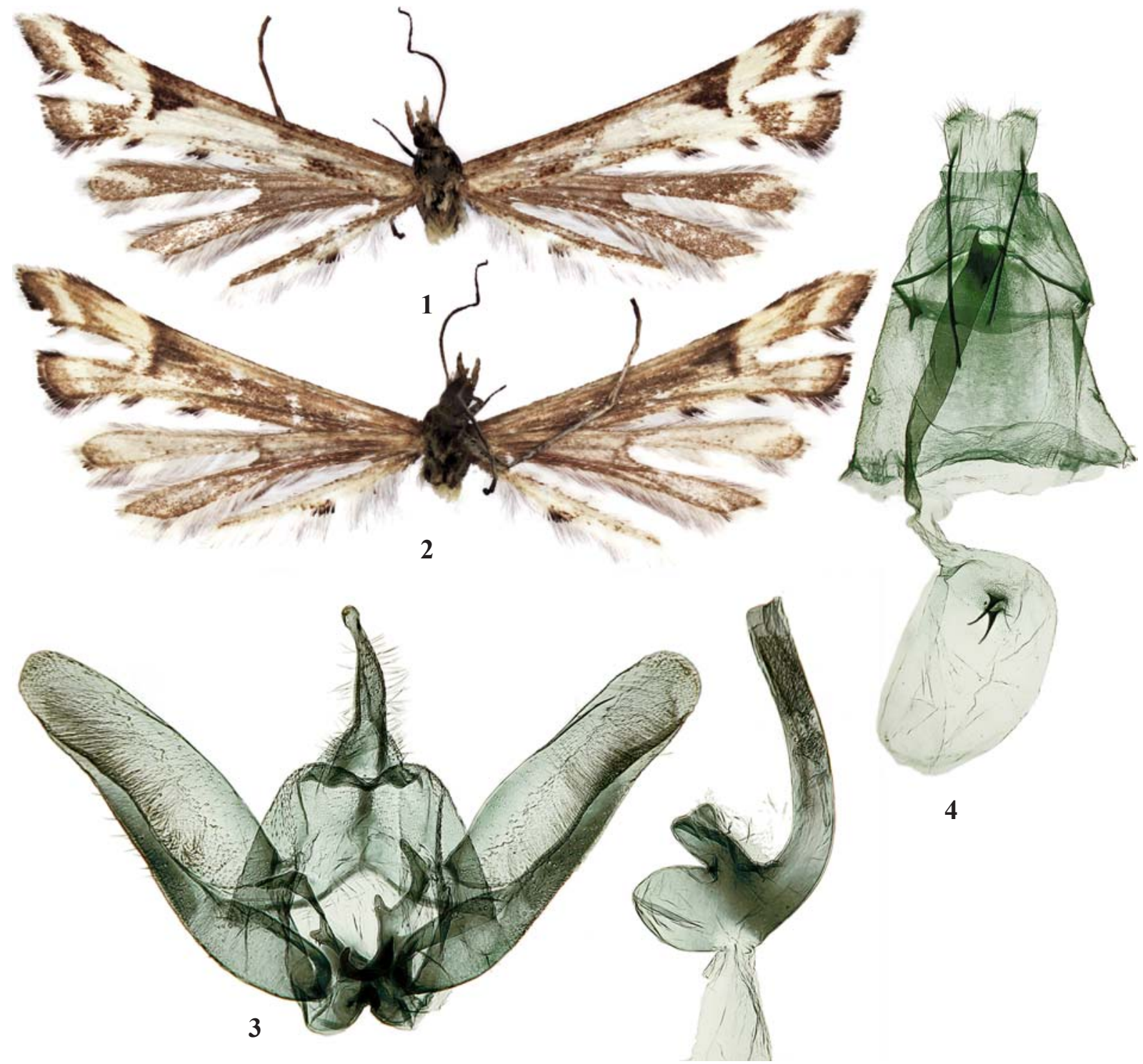

Figs 1-4. Platyptiia romanorum sp.n., 1 - adult, upperside; 2 - adult, underside; 3 - male genitalia; 4 - female genitalia.

Рис. 1-4. Platyptiia romanorum sp.n., 1 - имаго, сверху; 2 - имаго, снизу; 3 - половой аппарат самца; 4 - половой аппарат самки.

distal part. Antrum long, tubulate, sclerotized. Ductus short, membranous. Bursa rounded, with two narrow tapered signa.

DIAGNOSIS. In the genital structure, Platyptilia romanorum sp.n. is similar to the species group $P$. gonodactyla ([Denis et Schiffermüller], 1775) and P. calodactyla ([Denis et Schiffermüller], 1775). The genus Platyptilia is known for weak morphological differences in the genital structures of the species. But $P$. romanorum sp.n. differs well from all the known Palaearctic species of this genus by the pale, almost white color of the wings and by the pronounced white scales on the wings underside.

ECOLOGY. Highland species inhabiting the Alpine zone of the Altai-Sayan mountainous country at the altitudes from about $2200 \mathrm{~m}$ to $3000 \mathrm{~m}$. Flight of adults from the end of June to July.

DISTRIBUTION: Russia: Altai Republic (Ukok plateau, Kuraj, North-Chuya, South-Chuya Ranges), Kazakhstan: East- Kazakhstan Province (Tarbagatai Range).

ETYMOLOGY. The new species is named after two Russian entomologists, Roman Yakovlev and Roman Dudko, who were the first to find it in the Altai mountains.
ACKNOWLEDGEMENTS. The authors are grateful to the colleagues - entomologists R. Yakovlev, E. Gus'kova (Barnaul, Russia), R. Dudko, A. Nakonechnyi, V. Zinchenko, V. Ivonin (Novosibirsk, Russia), V. Doroshkin (Chelyabinsk, Russia) and A. Bidzilya (Kiev, Ukraine) for the unique material collected in the mountains of South Siberia. The results were obtained within the framework of the state task No. 6.2884.2017/4.6 Ministry of Education and Science of Russian Federation given to the first author of the article.

\section{References}

Ustjuzhanin P.Ya. 1996. Plume moths (Lepidoptera, Pterophoridae) of Siberia and the Russian Far East // Atalanta. Vol.27. Nos1/2. P.345-409.

Ustjuzhanin P.Ya., Kovtunovich V.N. 2007. Fauna of Plume Moths (Lepidoptera, Pterophoridae) the Altai Mts. within the limits of Russia and Kazakhstan // Altai zoological journal. Vol.1. P.43-51. 